Original Research Paper

\title{
Detection of tet Gene in Multidrug-Resistant Salmonella spp. Isolates from Layers and Broiler Breeders
}

\author{
${ }^{1}$ Agustin Indrawati, ${ }^{1}$ Leila Nur Azizah, ${ }^{1}$ I Wayan Teguh Wibawan, \\ ${ }^{1}$ Usamah Afiff, ${ }^{1}$ Safika, ${ }^{1}$ Maya Shofa and ${ }^{2}$ Siti Gusti Ningrum \\ ${ }^{I}$ Department of Animal Disease and Veterinary Public Health, IPB University, Bogor, Indonesia \\ ${ }^{2}$ Faculty of Veterinary Medicine, Universitas Wijaya Kusuma Surabaya, Surabaya, Indonesia
}

\author{
Article history \\ Received: 23-04-2020 \\ Revised: 04-06-2020 \\ Accepted: 17-06-2020 \\ Corresponding Author: \\ Agustin Indrawati \\ Department of Animal Disease \\ and Veterinary Public Health, \\ IPB University, Bogor, \\ Indonesia \\ Email: titin.seta@gmail.com
}

\begin{abstract}
The present study was conducted with the following aims: (i) To detect the multidrug-resistant Salmonella spp. isolates recovered from faeces, litter and drinking water in layers and broiler breeders' farms and (ii) to carried out the detection of the tet gene. A total of 21 Salmonella isolates were subjected to Polymerase Chain Reaction (PCR) assay to determine the presence of tet gene. Out of 21 isolates, 14 $(66.7 \%)$ and $7(33.3 \%)$ were found positive for tet(A) and tet(B), respectively. In antimicrobial susceptibility tests, the Salmonella isolates showed resistance to tetracycline, oxytetracycline, ampicillin, nalidixic acid, enrofloxacin, gentamicin and chloramphenicol. It can be concluded that the high prevalence of the tet gene indicates a high potential of Salmonella isolates for horizontal transmission of tetracycline resistance genes.
\end{abstract}

Keywords: Multidrug-Resistant, Salmonella, tet(A), tet(B)

\section{Introduction}

Resistance to tetracycline was widely observed in different niches of the environment (Huang et al., 2016; Jiang et al., 2018; Shi et al., 2019). Tetracycline resistance (tet) genes are one of the important determinants which enabling bacteria to resist tetracycline and are frequently associated with the development of Multidrug Resistance (MDR) in bacteria (Hedayatianfard et al., 2014). The tet genes such as tet(A) and tet(B) can promote drug efflux (Opal and PopVicas, 2015). Thus, drug efflux as a major mechanism of resistance to tetracyclines which could be find in enteric Gram-negative organism is encoded by tet genes (Giovanetti et al., 2003).

There are now over 40 recognized determinants of tetracycline resistance and tet(A) were frequently detected in different environments (Ling et al., 2013). Among the various tet genes, the tet(A) and tet(B) are significantly found in the Gram-negative bacteria (Jones et al., 2006). Salmonella played a big role in many outbreak investigations of poultry worldwide (Demirbilek, 2017). In Indonesia, control of Salmonella spp. in layers and breeders are difficult to perform since these bacteria are resistant to some antimicrobials (Gupta et al., 2019).

The prevalence of tet genes in Salmonella spp. of layers and broilers origin has not been previously reported from Indonesia. The present study was conducted with the following objectives: (i) To detect the multidrug-resistant Salmonella spp. isolates recovered from faeces, litter and drinking water in layers and broiler breeders' farms and (ii) to carry out the detection of the tet gene.

\section{Materials and Methods}

\section{Bacterial Isolation and Identification}

Cloacal swabs, litter and water samples were collected from layers and broiler breeder farms in Bandung and Purwakarta, West Java, Indonesia. A total of 70 these samples (cloacal swabs, litter and water) were prepared in Buffer Peptone Water (BWP). SNI (2008) for the identification procedure of Salmonella spp. was applied. Each sample (1 mL) was transferred into $50 \mathrm{~mL}$ of Tetrathionate Broth (TB) (Oxoid, UK) for the enrichment and incubated at $37^{\circ} \mathrm{C}$ for $18-24 \mathrm{~h}$. 
After the enrichment procedure, one loop of the broth was inoculated onto Salmonella Shigella Agar (SSA) (Oxoid, UK) for selective and differential procedures. After $18-24 \mathrm{~h}$ incubation at $37^{\circ} \mathrm{C}$, up to black coloured colonies were transferred onto Tripton Soy Agar (TSA) (Oxoid, UK) and incubated at $37^{\circ} \mathrm{C}$ for $24 \mathrm{~h}$. The isolates were characterized by Triple Sugar Iron Agar (TSIA), urea, indol, Methyl-Red (MR), Voges-Proskauer (VP) and Citrate (IMViC). Confirmation test for Salmonella spp. was performed by Polymerase Chain Reaction (PCR).

Genomic DNA was extracted using the boiling method (De Medici et al., 2003). Salmonella spp. was identified by PCR using specific nucleotide primers for detection of the in $\mathrm{Va}$ gene. The forward and reverse sequences of the primers were as follows 5'ACAGTGCTCGTTTACGACCTGAAT-3' and 5'AGACGACTGGTACTGATCGATAAT-3' (Chiu and Ou, 1996) respectively. Amplification of InvA was performed with (KAPA2G Fast Hotstart Readymix PCR kit, KAPA Biosystems, Cape Town, South Africa) in a total volume of $25 \mu \mathrm{L}$ with $2 \mu \mathrm{L}$ DNA template, $12.5 \mu \mathrm{L}$ master mix, $1.6 \mu \mathrm{L}$ primer forward $10 \mu \mathrm{M}, 1.6 \mu \mathrm{L}$ primer reverse 10 $\mu \mathrm{M}$ and $7.3 \mu \mathrm{L} \quad \mathrm{dH}_{2} \mathrm{O}$ (DNAse, RNAse free). Temperature conditions consisted of an initial $95^{\circ} \mathrm{C}$ denaturation step for $3 \mathrm{~min}$ followed by 35 cycles of $95^{\circ} \mathrm{C}$ for $30 \mathrm{~s}, 57.5^{\circ} \mathrm{C}$ for $1 \mathrm{~min}$ and $72^{\circ} \mathrm{C}$ for $1 \mathrm{~min}$. The final cycle was followed by one cycle at $72^{\circ} \mathrm{C}$ for $5 \mathrm{~min}$ in the thermal cycling system. The amplified fragments using standard PCR markers $\left(\mathrm{KAPA}^{\mathrm{TM}}\right.$ Universal Ladder, KAPA Biosystems) were evaluated using agarose gel electrophoresis.

\section{Antibiotic Susceptibility Testing}

Antibiotic susceptibility was determined by disk diffusion method of Kirby Bauer using the following disks (Oxoid, UK): Tetracycline (30 $\mu \mathrm{g} /$ disk), oxytetracycline (30 $\mu \mathrm{g} /$ disk), ampicillin (10 $\mu \mathrm{g} / \mathrm{disk})$, nalidixic acid (30 $\mu \mathrm{g} / \mathrm{disk})$, erythromycin (15 $\mu \mathrm{g} / \mathrm{disk})$, enrofloxacin $(15 \mu \mathrm{g} / \mathrm{disk})$, gentamicin $(10 \mu \mathrm{g} / \mathrm{disk})$ and chloramphenicol $(30 \mu \mathrm{g} / \mathrm{disk})$. Isolates were categorized as susceptible, intermediate and resistant based upon interpretative criteria developed by Clinical and Laboratory Standards Institute (CLSI, 2017).

Table 1: Primer sequences used in the PCR assay and the expected sizes of the products

\begin{tabular}{llll}
\hline $\begin{array}{l}\text { Target } \\
\text { gene }\end{array}$ & $\begin{array}{l}\text { Size } \\
\text { (bp) }\end{array}$ & Primer & Sequence \\
\hline tet(A) & 577 & TET(A)-F & 5'-GGTTCACTCGAACGACGTCA-3' \\
& & TET(A)-R & 5'-GGGCAGCAAATGTGGAGCAA-3' \\
tet(B) & 634 & TET(B)-F & $5^{\prime}$ '-CCTCAGCTTCTCAACCGCGTG-3' \\
& & TET(B)-R & $5^{\prime}$-GCACCTTGCTCATGACTCTT-3' \\
\hline
\end{tabular}

\section{Detection of tet(A) and tet(B) Genes}

The presence of tet(A) and tet(B) gene was determined with PCR. Specific nucleotide primers are listed in Table 1, according to Randall et al. (2004). PCR was performed in a total volume of $10 \mu \mathrm{L}$ with $1 \mu \mathrm{L}$ DNA template, $5 \mu \mathrm{L}$ master mix (KAPA2G Fast Hotstart Readymix PCR kit, KAPA Biosystems), $0.6 \mu \mathrm{L}$ primer forward $10 \mu \mathrm{M}, 0.6 \mu \mathrm{L}$ primer reverse $10 \mu \mathrm{M}$ and $3.8 \mu \mathrm{L} \mathrm{dH}_{2} \mathrm{O}$ (DNAse, RNAse free). A $1-\mu \mathrm{L}$ DNA template was added to the PCR solution, which underwent an initial denaturation step of $95^{\circ} \mathrm{C}$ for 3 min before 35 cycles of $95^{\circ} \mathrm{C}$ for $30 \mathrm{~s}, 50-60^{\circ} \mathrm{C}$ for $30 \mathrm{~s}$ and $72^{\circ} \mathrm{C}$ for $1 \mathrm{~min}$ and then a final step of $72^{\circ} \mathrm{C}$ for $5 \mathrm{~min}$ for the last cycle. The amplified fragments using standard PCR markers (KAPA ${ }^{\mathrm{TM}}$ Universal Ladder, KAPA Biosystems) were evaluated using agarose gel electrophoresis.

\section{Results}

\section{Identification of Salmonella spp. Isolates by PCR for InvA Gene}

The phenotyping was done for 33 Salmonella spp. isolates. Only 21 were identified as Salmonella spp. based on the presence of InvA gene by PCR. The detail of positive samples for Salmonella spp. is presented in Table 2.

\section{Multidrug Resistance}

The antibiotic resistance profiles of the Salmonella spp. isolates against eight antimicrobial agents are shown in Table 3, respectively. The results indicated that Salmonella spp. in this study were resistant to more than two of the eight antimicrobials which are tetracycline (100\%), ampicillin (100\%), oxytetracycline (95\%), nalidixic acid (95\%), erythromycin (80\%), enrofloxacin (71\%), gentamicin (43\%) and chloramphenicol $(24 \%)$, in declining order.

\section{Detection of tet $(A)$ and tet $(B)$ Genes}

All isolates of Salmonella spp. in the present study were resistant to tet genes. The tet genes distribution is listed in Table 4. Based on the results, most isolates were positive for tet $(\mathrm{A})(\mathrm{n}=14)$ (Fig. 2) compared to $\operatorname{tet}(\mathrm{B})(\mathrm{n}=7)($ Fig. 1).

Table 2: Results of identification of Salmonella spp. isolates by PCR for InvA gene

\begin{tabular}{lllll}
\hline & \multicolumn{2}{l}{ Sample n $(\%)$} & & \\
& ---------- & & \\
Farm & Faeces & Litter & Drinking water & n $(\%)$ \\
\hline Layer & $7(10)$ & $2(2.9)$ & $1(1.4)$ & $10(14.3)$ \\
Broiler & $4(5.7)$ & $3(4.3)$ & $4(5.7)$ & $11(15.7)$ \\
Total n $(\%)$ & $11(15.7)$ & $5(7.1)$ & $5(7.1)$ & $21(30)$ \\
\hline
\end{tabular}




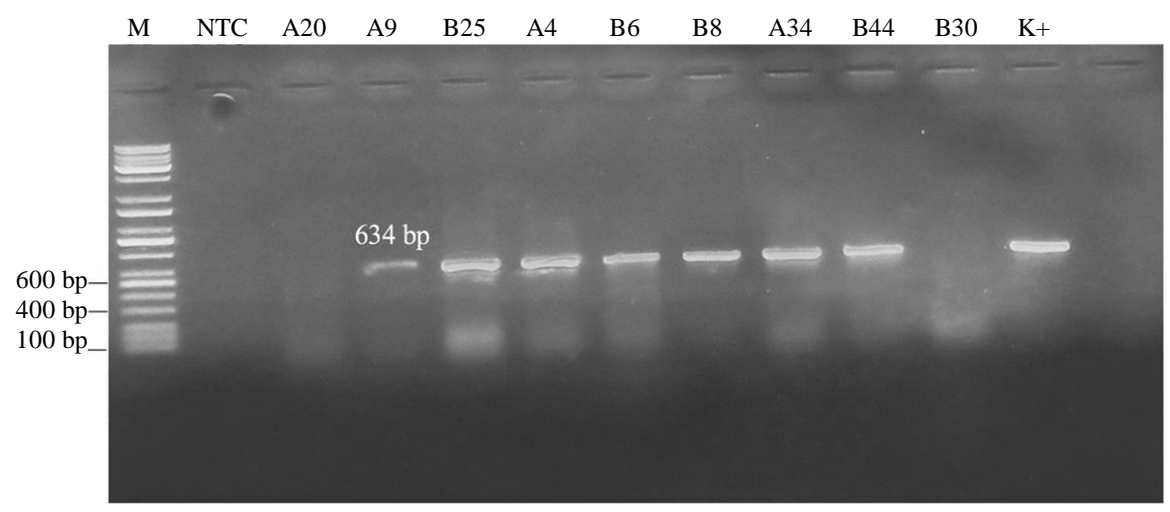

Fig. 1: Amplification of the tet(B) gene (634 bp) encoding tetracycline resistance in Salmonella spp.. A total of seven isolates showed positive results on tet(B). M: 100 bp (marker); NTC: Non-template control

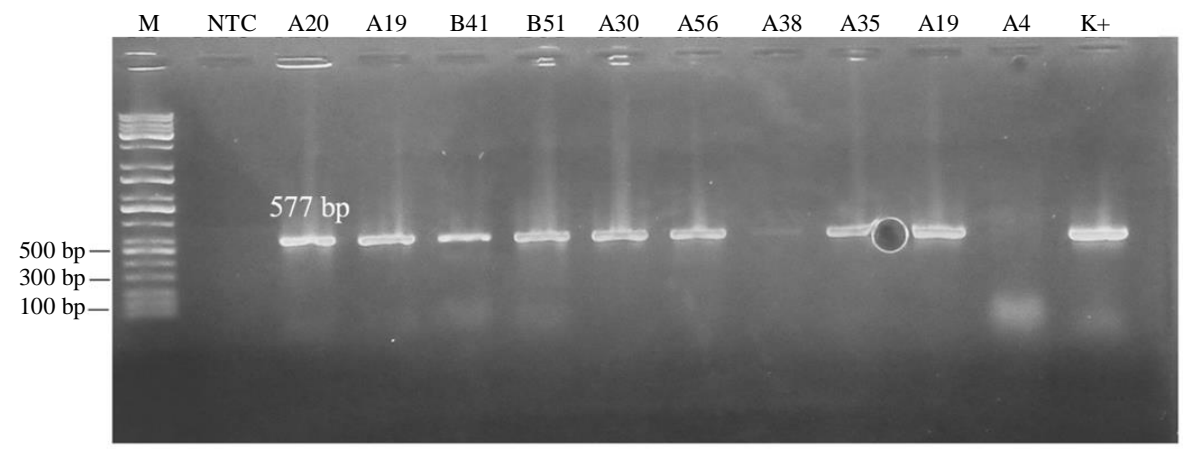

Fig. 2: Amplification of the tet(A) gene $(577 \mathrm{bp})$ encoding tetracycline resistance in Salmonella spp.. A total of 14 isolates showed positive results on tet(A). M: $100 \mathrm{bp}$ (marker); NTC: Non-template control

Table 3: The antibiotic resistance profiles of the Salmonella spp. isolates against eight antimicrobial agents

\begin{tabular}{|c|c|c|c|c|c|c|c|c|c|}
\hline No & Salmonella spp. & TET & OT & AMP & NA & $\mathrm{E}$ & ENR & $\mathrm{G}$ & $\mathrm{C}$ \\
\hline 1 & A34 & $\mathrm{R}$ & $\mathrm{R}$ & $\mathrm{R}$ & $\mathrm{R}$ & $\mathrm{R}$ & $\mathrm{R}$ & $\mathrm{R}$ & $\mathrm{R}$ \\
\hline 2 & $\mathrm{~A} 4$ & $\mathrm{R}$ & $\mathrm{R}$ & $\mathrm{R}$ & $\mathrm{R}$ & $\mathrm{R}$ & $\mathrm{R}$ & $\mathrm{R}$ & $\mathrm{S}$ \\
\hline 3 & B8 & $\mathrm{R}$ & $\mathrm{R}$ & $\mathrm{R}$ & $\mathrm{R}$ & $\mathrm{R}$ & $\mathrm{R}$ & $\mathrm{R}$ & $\mathrm{S}$ \\
\hline 4 & B19 & $\mathrm{R}$ & $\mathrm{R}$ & $\mathrm{R}$ & $\mathrm{R}$ & I & $\mathrm{R}$ & $\mathrm{S}$ & $\mathrm{R}$ \\
\hline 5 & B38 & $\mathrm{R}$ & $\mathrm{R}$ & $\mathrm{R}$ & $\mathrm{R}$ & I & $\mathrm{R}$ & $\mathrm{S}$ & $\mathrm{S}$ \\
\hline 6 & A51 & $\mathrm{R}$ & $\mathrm{R}$ & $\mathrm{R}$ & $\mathrm{R}$ & $\mathrm{R}$ & I & $\mathrm{S}$ & $\mathrm{S}$ \\
\hline 7 & A41 & $\mathrm{R}$ & $\mathrm{R}$ & $\mathrm{R}$ & $\mathrm{R}$ & $\mathrm{R}$ & S & $\mathrm{S}$ & $\mathrm{S}$ \\
\hline 8 & A6 & $\mathrm{R}$ & $\mathrm{R}$ & $\mathrm{R}$ & $\mathrm{R}$ & $\mathrm{R}$ & S & $\mathrm{S}$ & $\mathrm{S}$ \\
\hline 9 & A9 & $\mathrm{R}$ & $\mathrm{R}$ & $\mathrm{R}$ & $\mathrm{R}$ & $\mathrm{R}$ & $\mathrm{R}$ & $\mathrm{R}$ & $\mathrm{R}$ \\
\hline 10 & A30 & $\mathrm{R}$ & $\mathrm{R}$ & $\mathrm{R}$ & $\mathrm{R}$ & $\mathrm{R}$ & $\mathrm{R}$ & & $\mathrm{R}$ \\
\hline 11 & A19 & $\mathrm{R}$ & $\mathrm{R}$ & $\mathrm{R}$ & $\mathrm{R}$ & $\mathrm{R}$ & $\mathrm{R}$ & $\mathrm{R}$ & $\mathrm{R}$ \\
\hline 12 & B41 & $\mathrm{R}$ & S & $\mathrm{R}$ & $\mathrm{R}$ & $\mathrm{S}$ & I & $\mathrm{S}$ & I \\
\hline 13 & B6 & $\mathrm{R}$ & $\mathrm{R}$ & $\mathrm{R}$ & $\mathrm{R}$ & $\mathrm{R}$ & I & $\mathrm{R}$ & I \\
\hline 14 & A27 & $\mathrm{R}$ & $\mathrm{R}$ & $\mathrm{R}$ & $\mathrm{R}$ & $\mathrm{S}$ & $\mathrm{R}$ & I & I \\
\hline 15 & A25 & $\mathrm{R}$ & $\mathrm{R}$ & $\mathrm{R}$ & $\mathrm{R}$ & $\mathrm{R}$ & $\mathrm{R}$ & $\mathrm{S}$ & I \\
\hline 16 & B35 & $\mathrm{R}$ & $\mathrm{R}$ & $\mathrm{R}$ & $\mathrm{R}$ & $\mathrm{R}$ & $\mathrm{R}$ & $\mathrm{S}$ & $\mathrm{S}$ \\
\hline 17 & A56 & $\mathrm{R}$ & $\mathrm{R}$ & $\mathrm{R}$ & $\mathrm{R}$ & $\mathrm{R}$ & $\mathrm{R}$ & $\mathrm{S}$ & I \\
\hline 18 & B44 & $\mathrm{R}$ & $\mathrm{R}$ & $\mathrm{R}$ & $\mathrm{S}$ & $\mathrm{R}$ & I & I & I \\
\hline 19 & A20 & $\mathrm{R}$ & $\mathrm{R}$ & $\mathrm{R}$ & $\mathrm{R}$ & $\mathrm{R}$ & $\mathrm{R}$ & $\mathrm{R}$ & I \\
\hline 20 & B25 & $\mathrm{R}$ & $\mathrm{R}$ & $\mathrm{R}$ & $\mathrm{R}$ & $\mathrm{R}$ & $\mathrm{R}$ & $\mathrm{R}$ & I \\
\hline 21 & A 21 & $\mathrm{R}$ & $\mathrm{R}$ & $\mathrm{R}$ & $\mathrm{R}$ & $\mathrm{R}$ & $\mathrm{R}$ & I & I \\
\hline $\mathrm{S}(\%)$ & & - & 5 & - & 5 & 10 & 10 & 43 & 33 \\
\hline I $(\%)$ & & - & - & - & - & 10 & 19 & 14 & 43 \\
\hline $\mathrm{R}(\%)$ & & 100 & 95 & 100 & 95 & 80 & 71 & 43 & 24 \\
\hline
\end{tabular}

TET (tetracycline), OT (oxytetracycline), AMP (ampicillin), NA (nalidixic acid), E (erythromycin), ENR (enrofloxacin), G (gentamicin), C (chloramphenicol), S (sensitive), I (intermediate), R (resistant) 
Table 4: The distribution of $\operatorname{tet}(A)$ and $\operatorname{tet}(B)$ genes

\begin{tabular}{|c|c|c|c|c|}
\hline No. & Sample code & Poultry flock (layers/broiler breeder) & $\operatorname{tet}(\mathrm{A})(+/-)$ & $\operatorname{tet}(\mathrm{B})(+/-)$ \\
\hline$\overline{1}$ & $\mathrm{~A} 34$ & Layer & - & + \\
\hline 2 & A4 & Broiler breeder & - & + \\
\hline 3 & $\mathrm{~B} 8$ & Layer & - & + \\
\hline 4 & B19 & Broiler breeder & + & - \\
\hline 5 & B38 & Broiler breeder & + & - \\
\hline 6 & A51 & Layer & + & - \\
\hline 7 & A41 & Layer & + & - \\
\hline 8 & A6 & Broiler breeder & + & - \\
\hline 9 & A9 & Broiler breeder & - & + \\
\hline 10 & A30 & Layer & + & - \\
\hline 11 & A19 & Layer & + & - \\
\hline 12 & B41 & Broiler breeder & + & - \\
\hline 13 & B6 & Broiler breeder & - & + \\
\hline 14 & A27 & Layer & + & - \\
\hline 15 & A25 & Layer & + & - \\
\hline 16 & B35 & Broiler breeder & + & - \\
\hline 17 & A56 & Layer & + & - \\
\hline 18 & B44 & Broiler breeder & - & + \\
\hline 19 & A20 & Broiler breeder & + & - \\
\hline 20 & $\mathrm{~B} 25$ & Broiler breeder & - & + \\
\hline \multirow[t]{2}{*}{21} & A21 & Layer & + & - \\
\hline & & Total & 14 & 7 \\
\hline
\end{tabular}

\section{Discussion}

Salmonella spp. has been recognized as a global threat and raises public health concerns since these bacteria have a number of virulence mechanism to interfere with host defence systems in different infection stages. In addition Salmonella may develop resistance to antibiotics (Mouttotou et al., 2017). Resistance to antibiotics in Salmonella spp. is significant in poultry isolates from Indonesia. In the present study the results of antibiotic sensitivity test (Table 3) indicated that all Salmonella spp. are resistant to tetracycline. Our results agreed with previous study (Yulistiani et al., 2017). The high resistance to tetracycline in poultry farm caused by the abundant and quite long use of tetracycline on poultry farms. Although, Indonesia has banned the use of antibiotic growth promoter in farms, farmers are still using antibiotics to overcome the problem of Salmonellosis on their farms.

Because of the frequent use of antibiotics for the therapy, bacteria may develop multidrug resistant phenotype (Chatterjee et al., 2019). The high number of Salmonella spp. infections despite antibiotic therapy raises several questions such as: Are available antibiotics efficient for the therapy of existing Salmonella spp.? Therefore, a few farmers start using vaccinations to treat Salmonella spp.. In this investigation Salmonella was identified in $30 \%$ of samples collected from several commercial layer and broiler breeder farms in Purwakarta, Indonesia. Another finding (Li et al., 2017) from layer farms also detected Salmonella spp. using PCR targeting InvA gene with a low prevalence of $11.6 \%$. In the present study, a total of 21 isolates of Salmonella spp. (30\%) were found in faeces $(15.7 \%)$, litter $(7.1 \%)$ and drinking water (7.1\%). The distribution of Salmonella spp. in this study is higher compare to previous results (Abunna et al., 2016) that found $15.12 \%$ of Salmonella spp. isolates from cloacal swabs, fresh faeces, litter and poultry drinking water samples. The results in this study also showed that cases of salmonellosis were higher in commercial layer chickens than in broiler breeders. This distribution agreed with previous studies (Shoaib et al., 2019). This is not surprising because sanitation in the environment of broiler breeder farms is better than commercial layer farms in Indonesia, generally.

Also, the discovery of Salmonella spp. in drinking water indicates the possibility of contamination from the environment. Most likely, these chickens are infected from their drinking water contaminated by Salmonella spp.. The Salmonella contamination at this site probably caused by a biofilm formation by Salmonella spp. (Merino et al., 2019) on the waterline or the water source are not free from Salmonella spp.. To figure it out, more investigation is needed.

The investigation was continued to address the question of unsuccessful handf of Salmonellosis in these farms. Based on the results of the investigation, all Salmonella spp. isolates were resistant to at least three of the antibiotics tested. These results show that the isolates are multidrug resistant. Besides, all Salmonella isolates in this study showed $100 \%$ resistance to tetracycline and ampicillin. In Indonesia, the types of antibiotics that are still used for Salmonella control in poultry include enrofloxacin, a combination of ampicillin and colistin 
sulphate, a combination of ciprofloxacin and tylosin tartrate, floxamycine and a combination of amoxicillin and colistin sulphate. Therefore, the prevalence of Salmonella resistant to tetracycline in these farms was surprisingly high, considering that this antibiotic is not used anymore in Indonesia. This observation could address that the high prevalence of Salmonella spp. in these farms are not linked to the antibiotic usage. The previously finding by Liljebjelke et al. (2017) also showed that the therapeutic use of tetracycline in Salmonella spp. was not efficient. Therefore, detection of tet(A) (Fig. 2) and tet(B) genes (Fig. 1) was applied in this study. Based on the results, these genes are distributed in both types of farms with a greater distribution is tet(A) gene. The results in this study about the distribution of $\operatorname{tet}(\mathrm{A})$ and tet(B) genes were in confirmation with Waghamare et al. (2018) who reported that all Salmonella spp. were found to carry tet(A) while none of their isolates carried $\operatorname{tet}(\mathrm{B})$. The $\operatorname{tet}(\mathrm{A})$ and $\operatorname{tet}(\mathrm{B})$ are the genes of the tetracycline resistance related to an efflux mechanism (Roberts and Schwarz, 2017) and it could be present in mobile elements and acquired by horizontal transfer by Salmonella spp.. It is not surprising since efflux pumps are the most abundant in Gram-negative bacteria (Gharajalar and Sofiani, 2017). Our result confirms the spread of multidrug-resistant Salmonella spp. from commercial layer and breeder broiler farms. The occurrence of multidrug resistant Salmonella spp. in poultry farms in Indonesia present a significant risk to human health.

\section{Conclusion}

The prevalence of tetracycline and ampicillin in commercial layer and broiler breeder farms was high. This study revealed a significant rise in tetracycline resistance with presence of tet(A) and tet(B) genes in Salmonella spp. Dissemination of multidrug-resistant Salmonella spp. observed in commercial layer and broiler breeder farms may pose a serious risk to human health.

\section{Acknowledgement}

We wish to thank the College of Veterinary Medicine at IPB University, Prof. Dr Fachriyan H. Pasaribu for the support this work and the poultry companies, PT Charoen Pokphand participated in the present study.

\section{Funding Information}

This work was supported by a grant from INSINAS RESEARCH PRATAMA INDIVIDU (12/INS1/PPK/E\$/2018).

\section{Author's Contributions}

Leila Nur Azizah, Maya Shofa and Usamah Afiff:

Prepared the protocol.

Agustin Indrawati, I Wayan Teguh Wibawan and

Safika: Developed the study.

Siti Gusti Ningrum: Drafted and corrected the manuscript.

All authors read and approved the final manuscript.

\section{Ethics}

The authors declare that there are no conflicts of interest or any ethical issues.

\section{References}

Abunna, F., M. Bedasa, T. Beyene, D. Ayana and B. Mamo et al., 2016. Salmonella: Isolation and antimicrobial susceptibility tests on isolates collected from poultry farms in and around Modjo, Central Oromia and Ethiopia. J. Anim. Poultry Sci., 5: 21-35.

Chatterjee, R., S. Paul and Rama, 2019. Global Use of antimicrobials in food animals, emergence of antimicrobial resistance and way forward: An overview. Indian J. Anim. Health, 58: 19-32.

DOI: 10.36062/ijah.58.2SPL.2019.19-32

Chiu, C.H. and J.T. Ou, 1996. Rapid identification of Salmonella serovars in faeces by specific detection of virulence genes, invA and $\mathrm{spvC}$, by an enrichment broth culture-multiplex PCR combination assay. J. Clin. Microbiol., 34: 2619-2622.

CLSI, 2017. Performance Standards for Antimicrobial Disk Susceptibility Tests. 11th Edn., Clinical and Laboratory Standarts Institute, Wayne, PA.

De Medici, D., L. Croci, E. Delibato, S. Di Pasquale and E. Filetici et al., 2003. Evaluation of DNA extraction methods for use in combination with SYBR green I real-time PCR to detect Salmonella enterica serotype enteritidis in poultry. Applied Environ. Microbiol., 69: 3456-3461. DOI: 10.1128/AEM.69.6.3456-3461.2003

Demirbilek, S.K., 2017. Salmonellosis in Animals. In: Salmonella-A Re-emerging Pathogen, Mascellino, M.T. (Ed.), IntechOpen.

Gharajalar, S.N. and V.H. Sofiani, 2017. Patterns of efflux pump genes among tetracycline resistance uropathogenic Escherichia coli isolates obtained from human urinary infections. Jundishapur $\mathrm{J}$. Microbiol., 10: e40884-e40884.

DOI: $10.5812 / \mathrm{jjm} .40884$ 
Giovanetti, E., A. Brenciani, R. Lupidi, M.C Roberts and P.E. Varaldo, 2003. Presence of the tet $(\mathrm{O})$ gene in erythromycin-and tetracycline-resistant strains of Streptococcus pyogenes and linkage with either the mef (A) or the erm (A) gene. Antimicrobial Agents Chemotherapy, 47: 2844-2849.

DOI: 10.1128/AAC.47.9.2844-2849.2003

Gupta, R., S.L. Chauhan, S. Kumar, N. Jindal and N.K. Mahajan et al., 2019. Carriage of class 1 integrons and molecular characterization of intI1 gene in multidrug-resistant Salmonella spp. isolates from broilers. Vet. World, 12: 609-613.

DOI: $10.14202 /$ vetworld.2019.609-613

Hedayatianfard, K., M. Akhlaghi and H. Sharifiyazdi, 2014. Detection of tetracycline resistance genes in bacteria isolated from fish farms using polymerase chain reaction. Vet. Res. Forum, 5: 269-275.

PMID: 25610578

Huang, J.J., J. Xi, H.Y. Hu, Y. Li and S.Q. Lu et al., 2016. UV light tolerance and reactivation potential of tetracycline-resistant bacteria from secondary effluents of a wastewater treatment plant. J. Environ. Sci., 41: 146-153. DOI: 10.1016/j.jes.2015.04.034

Jiang, H., R. Zhou, Y. Yang, B. Chen and Z. Cheng et al., 2018. Characterizing the antibiotic resistance genes in a river catchment: Influence of anthropogenic activities. J. Environ. Sci., 69: 125-132.

DOI: $10.1016 /$ j.jes.2017.08.009

Jones, C.H., M. Tuckman, E. Murphy and P.A. Bradford, 2006. Identification and sequence of a tet (M) tetracycline resistance determinant homologue in clinical isolates of Escherichia coli. J. Bacteriol., 188: 7151-7164. DOI: $10.1128 /$ JB.00705-06

Li, X., L. Liu, Q. Li, G. Xu and J. Zheng, 2017. Salmonella contamination in layer farms of different scales in China: Detection and ERIC-PCR analysis. J. Poultry Sci. DOI: 10.2141/jpsa.0160144

Liljebjelke, K.A., C.L. Hofacre, D.G. White, S. Ayers and M.D. Lee et al., 2017. Diversity of antimicrobial resistance phenotypes in Salmonella isolated from commercial poultry farms. Frontiers Vet. Sci., 4: 96-96. DOI: 10.3389/fvets.2017.00096

Ling, Z., Y. Yang, Y. Huang, S. Zou and T. Luan, 2013. A preliminary investigation on the occurrence and distribution of antibiotic resistance genes in the Beijiang River, South China. J. Environ. Sci., 25: 1656-1661. DOI: 10.1016/S1001-0742(12)60223-X

Merino, L., F. Procura, F.M. Trejo, D.J. Bueno and M.A. Golowczyc, 2019. Biofilm formation by Salmonella sp. in the poultry industry: Detection, control and eradication strategies. Food Res. Int., 119: 530-540. DOI: 10.1016/j.foodres.2017.11.024
Mouttotou, N., S. Ahmad, Z. Kamran and K.C. Koutoulis, 2017. Prevalence, Risks and Antibiotic Resistance of Salmonella in Poultry Production Chain. In: Current Topics in Salmonella and Salmonellosis, Mares, M. (Ed.), IntechOpen, pp: 215-134.

Opal, S.V. and A. Pop-Vicas, 2015. Molecular mechanism of antibiotic resistance in bacteria. In: Mandell, Douglas and Bennett's Principles and Practice of Infectious Diseases, pp. 235-251.

Randall, L.P., S.W. Cooles, M.K. Osborn, L.J.V. Piddock and M.J. Woodward, 2004. Antibiotic resistance genes, integrons and multiple antibiotic resistance in thirty-five serotypes of Salmonella enterica isolated from humans and animals in the UK. J. Antimicrobial Chemotherapy, 53: 208-216. DOI: $10.1093 / \mathrm{jac} / \mathrm{dkh} 070$

Roberts, M.C. and S. Schwarz, 2017. Tetracycline and Chloramphenicol Resistance Mechanisms. In: Antimicrobial Drug Resistance, Springer, Cham, pp: 231-243.

Shi, Y., Z. Tian, S.O. Leclercq, H. Zhang and M. Yang et al., 2019. Genetic characterization and potential molecular dissemination mechanism of tet (31) gene in Aeromonas caviae from an oxytetracycline wastewater treatment system. J. Environ. Sci., 76: 259-266.

DOI: $10.1016 /$ j.jes.2018.05.008

Shoaib, M., A. Riaz, M. Ul Hassan, A. Yousaf and S.U. Rehman et al., 2019. Sero-prevalence and associated risk factors of mycoplasma gallisepticum, Mycoplasma synoviae and Salmonella Pullorum/Gallinarium in poultry. Pak. Vet. J. DOI: $10.29261 /$ pakvetj/2019.097

SNI, 2008. Metode pengujian cemaran mikroba dalam daging, telur dan susu, serta hasil: SNI 2897:2008. Badan Standardisasi Nasional.

Waghamare, R.N., A.M. Paturkar, V.M. Vaidya, R.J. Zende and Z.N. Dubal et al., 2018. Phenotypic and genotypic drug resistance profile of Salmonella serovars isolated from poultry farm and processing units located in and around Mumbai city, India. Vet. World, 11: 1682-1688.

DOI: 10.14202/vetworld.2018.1682-1688

Yulistiani, R., D. Praseptiangga, D. Raharjo and T. Shirakawa, 2017. Prevalence of antibiotic-resistance enterobacteriaceae strains isolated from chicken meat at traditional markets in Surabaya, Indonesia. Mat. Sci. Eng. DOI: 10.1088/1757-899X/193/1/012007 